\title{
PLURALISME EKONOMI DALAM MENINGKATKAN KEMAMPUAN BERFIKIR KRITIS MAHASISWA
}

\author{
Mica Siar Meiriza ${ }^{1)}$ \\ ${ }^{1)}$ Fakultas Ekonomi, Universitas Negeri Medan \\ Email: althamira@yahoo.com
}

\begin{abstract}
Abstrak
Kemampuan berfikir kritis merupakan salah satu kompetensi yang harus dimiliki mahasiswa guna mempersiapkan mereka ikut berpartisipasi dalam kehidupan sosial dan ekonomi setelah kelulusannya. Penelitian ini dilatarbelakangi oleh rendahnya kemampuan berfikir kritis mahasiswa dalam melakukan analisis keanekaragaman perspektif teoritis ekonomi akibat dari proses kegiatan pembelajaran yang bersifat monis, yaitu mengajarkan ekonomi dari satu perspektif ekonomi saja yaitu ortodoks. Sistem pembelajaran yang bersifat monis seperti ini hanya menyentuh nilai dan teori-teori ortodoksi ekonomi yang jauh dari ekonomi dunia nyata sehingga tidak mampu meningkatkan keterlibatan aktif dan kritis mahasiswa. Dampaknya tentu saja pada capaian pembelajaran yang dihasilkan. Penelitian ini bertujuan untuk meningkatkan kemampuan berfikir kritis mahasiswa dalam memahami keanekaragaman perspektif teoritis ekonomi melalui pluralisme ekonomi yaitu mengajarkan ekonomi melalui berbagai perspektif yang ada tidak hanya perspektif ortodoks tetapi juga perspektif heterodoks. Penelitian ini menggunakan pendekatan deskriptif kuantitatif. Untuk memperoleh data yang diperlukan, penulis menggunakan metode tes dan wawancara dan data dianalisis dalam bentuk persentase. Hasil penelitian menunjukkan: (1) $90,8 \%$ mahasiswa telah mencapai indikator menganalisis argument. (2) $88,3 \%$ mahasiswa telah mencapai indikator mengevaluasi informasi. (3) $86,7 \%$ mahasiswa telah mencapai indikator mensintesis bukti. (4) $86,7 \%$ mahasiswa telah mencapai indikator menarik kesimpulan. Hambatan yang dihadapi mahasiswa ketika dilakukan wawancara adalah beberapa mahasiswa bingung dengan beberapa perspektif yang berbeda serta kesalahan informasi dan gambar yang tidak sesuai dengan soal.
\end{abstract}

Kata Kunci : Ortodoks, Heterodoks, Pluralisme Ekonomi, Berfikir Kritis. 


\section{PENDAHULUAN}

Selama ini, pembelajaran ekonomi yang dilakukan hampir sebagian besar universitas di dunia, termasuk di Indonesia (Mubyarto, 2002) masih bersifat monis yaitu membelajarkan ekonomi melalui satu perspektif yaitu ortodoks yang bersifat dogmatis dengan mengajarkan perspektif Klasik dan Neoklasik (Denis, 2009). Pendapat ini juga semakin diperkuat oleh Patunru seorang dosen di Universitas Indonesia yang menegaskan bahwa buku teks ekonomi yang sering dijadikan referensi pembelajaran adalah Samuelson dan Nordhaus (2009, edisi terkini) disamping buku teks Mankiew (2008) yang dianggap masih bersifat pragmatis (Patunru, 2010). Sistem pembelajaran yang bersifat monis seperti ini sulit dibuktikan ketika diuji dengan bukti empiris. Ketidaksesuaian antara apa yang dipelajari dengan keadaan dunia nyata membatasi pemikiran kritis mahasiswa untuk memahami keadaan perekonomian dengan lebih baik. Mahasiswa juga sulit mengembangkan keterampilan yang dibutuhkan dalam dunia kerja serta sulit berinteraksi secara sosial dan ekonomi yang lebih luas (Juniper, dkk; 2015).

Krisis keaungan global dan ekonomi yang terus terjadi mempertegas pernyataan bahwa ada kesalahan yang terus dilakukan pada kurikulum di perguruan tinggi yang mengajarkan ekonomi tidak sesuai dengan keadaan ekonomi dunia nyata (Juniper, ddk, 2015). Oleh karena itu perlu dilakukan reformasi praktik pengajaran ekonomi dengan mengedepankan keragaman intelektual dan kurikulum yang ada, ditandai oleh kemajemukan dan keterampilan refleksif dan kritis (Negru, 2010).

\section{TINJAUAN PUSTAKA Ortodoks}

Secara etimologi, kata ortodoks berasal dari bahasa yunani, yaitu "orthos" yang artinya benar dan "doxa" yang artinya pandangan (Collins Dict). Jadi, ortodoks merupakan pandangan dan tradisi yang diterima dalam ekonomi (Jackson, 2017: 2).

Buku teks ekonomi yang digunakan dan diajarkan hampir disebagian besar perguruan tinggi di dunia merujuk pada buku Paul Samuelson yang berjudul Economics An Introductory Analysis, dimana inti ajaranya dikenal dengan teori ekonomi ortodoks (Neoklasik) (Mubyarto, 2002). Pembahasan
NIAGAWAN Vol 8 No 3 November 2019 ajaran ortodoks berkenaan dengan growth, production dan wealth dengan asumsi-asumsi rationality, individualism dan equilibrium (Arnsperger \& Varoufakis, 2006). Penekanan ekonomi ortodok pada mekanisme pasar persaingan bebas, dengan asumsi-asumsi tertentu menuju keseimbangan dan efisiensi optimal yang baik bagi setiap orang. Maksud dari pernyataan ini adalah pasar dibiarkan bebas tanpa ada campur tangan pemerintah meskipun campur tangan tersebut dianggap baik sekalipun, maka masyarakat akan mencapai kesejahteraan bersama secara optimal (pareto optimal) (Santosa, 2010).

Dominasi Ortodoks hampir di seluruh kegiatan ekonomi dunia tidak terlepas dari keberhasilan Negara-negara maju mensejahterakan masyarakatnya sehingga berpengaruh pada penguasaan ilmu pengetahuan dan teknologi. Selain itu, banyak Negara-negara berkembang juga bekas jajahan Negara maju, sehingga mereka ikut menerapkan ekonomi ortodoks (Mubyarto, 2002).

Dalam melakukan analisis ekonominya, ekonomi ortodoks lebih menekankan pada metode kuantitatifnya, sehingga persoalanpersoalan ekonomi yang muncul selalu diselesaikan dengan perhitungan matematika, statistik dan ekonometrika (Santosa, 2010) sehingga bertentangan ketika diuji secara empiris. Pendapat ini juga mendapat dukungan dari hasil penelitian Collander (2001) yang memperlihatkan 98\% mahasiswa ekonomi beranggapan bahwa pengetahuan matematika sangat penting dalam mempelajari ilmu ekonomi. Inilah sebabnya para ekonom selalu memberikan kesimpulan dan rekomendasi ekonomi yang begitu dangkal akibat mereka lebih menguasai alat daripada substansi sehingga fenomena ekonomi yang menjadi substansi yang lebih penting tidak terlihat (Santoso, 2010). Disamping itu, ekonomi ortodoks juga menyingkirkan sejarah dalam kerangka analisisnya. Sifat ortodoks juga tandus akan nilai karena tema utama pembahasannya telah mengesampingkan persoalan-persoalan poverty, moral dan justice yang seharusnya lebih mendapat perioritas jika di pandang dari sisi kemanusiaan. Perspektif yang dibangun berdasarkan pada asumsi-asumsi dan lebih mengedepankan pendekatan matematika, mengesampingkan sejarah dari kerangka analisisnya dan mereduksi perilaku manusia (human Behavior) tentu saja terbatas dalam 
menjelaskan kondisi dunia nyata (Raveaud, 2009: 2)

\section{Heterodoks}

Secara etimologi, heterodoks berasal dari bahasa Yunani, yaitu "hetero" yang artinya berbeda dan "doxa" yang artinya pandangan (Collins Dict). Para ekonom mendefenisikan ekonomi heterodoks sebagai analisis dan pembelajaran prinsif-prinsif ekonomi di luar mainstream atau ekonomi ortodoks (Lee, 2009). Atau dengan kata lain, ekonomi heterodoks adalah perbincangan ekonomi di luar mainstream atau ekonomi ortodoks. Kemunculan ekonomi heterodoks didasarkan pada tulisan Kuhnian yang berjudul The Structure of Scientific Revolution (1962 dan 1970) yang berbicara mengenai konflik teoritis dan pergeseran paradigma dalam ilmu alam (Garnett, 2006: 523) pada Tahun 60-an (Backhaouse, 2000: 150-154) hingga awal 1980an dan dianggap sebagai gerakan pluralism pertama. Pandangan radikal Kuhnian ini memberikan kepercayaan diri para ekonom non ortodoks untuk membentuk paradigma teoritis mereka sendiri menjadi ortodoksi yang berkuasa, kebenaran ekonomi baru menggantikan paradigma ekonomi mainstream (Garnett, 2006: 522). Pergerakan ini diawali oleh Austrian, Marxian, Sraffan, Post-Keynesian, institusionalist dan teori New-classical yang menentang makro-mikro ortodoks dan membangun paradigma alternatif yang mereka anggap paling tepat dalam menangani masalah makro-mikro. (Dolan, 1979; Desai, 1979; Steedman, 1977; Kregel 1975; dan Tool; 1979). Heterodoks Kuhnian ini mempunyai tujuan"to cunstruct a unique, superior and ultimately hegemonic paradigm(s) of mainstream economics" (Garnett, 2006: 521) dan tidak mau bekerjasama dengan paradigma yang berbeda dan menentang toleransi antar perspektif yang berbeda (Marqués \& Weisman, 2009: 75). Dibawah payung heterodoks, mereka menolak atau mengkritik sistem ekonomi ortodoks terutama dalam menangani persoalan dan masalah ekonomi (Lee, 2011).

Dalam ekonomi heterodoks, Seperti yang ditekankan oleh Shadmehri, Khadem \& Ghadimi (2014: 4) bahwa tidak ada istilah "single heterodoks economics theory" dalam heterodoks, melainkan ada begitu bayak teori yang kesemuanya menentang teori ortodoks dalam memahami bagaimana ekonomi dan
NIAGAWAN Vol 8 No 3 November 2019 kehidupan sosial bekerja. Beberapa hal yang menjadi perhatian dan kritik ekonomi heterodoks terhadap ekonomi ortodoks adalah mengenai "rationality of economic agent". Ortodoks meyakini bahwa setiap individu akan bersikap rasional dan berusaha memaksimalkan utilitas individual mereka (atau keuntungan) saat melakukan pilihan (rational choice theory), sementara heterodoks menganggap bahwa manusia bukanlah mesin pencari kesenangan (pleasure seeking machine) yang hanya mencari utilitas maksimum. Pada prinisipnya manusia yang menjadi subjek ekonomi sulit diprediksi (unpredictable). Oleh sebab itu, asumsi yang mengatakan bahwa setiap individu pasti berlaku rasional tidak dapat diterima. Kritik heterodoks berikutnya mengenai model keseimbangan pasar. Ortodoks meyakini bahwa keseimbangan pasar terjadi ketika ada interaksi murni antara penawaran dan permintaan (market clearing). Harga yang terbentuk di pasar merupakan harga yang dihasilkan hanya oleh interaksi antara penawaran dengan permintaan. Heterodoks menentang hal ini karena dinilai tidak mampu menjelaskan keadaan di dalam dunia nyata, dimana banyak komponen lain yang menentukan harga. Kritik selanjutnya yang dilakukan heterodoks adalah terhadap model pasar tenaga kerja yang merasionalisasi eksploitasi atas buruh (labor) oleh pemilik modal (kapitalis). Disini dapat dilihat bahwa heterodoks lebih mengedepankan asumsi-asumsi yang lebih luas serta lebih mampu memberikan penyelesaian yang lebih komprehensif dalam masalah ekonomi.

Sayangnya gerakan pluralisme pertama ini dianggap belum sesuai dengan harapan dan cita-cita mahasiswa dan perguruan tinggi. Akibat dari ketidakpuasan ini, maka gelombang pluralisme kedua muncul akibat dari ketidakpuasan terhadap aliran pemikiran Kuhnian yang menyatakan "not just polite tolerance among parallel school, each with its own truth" but "active dialog and mutual learning among self-consciously partial perspectives" (Fullbrook, 2009). Jika gelombang pluralisme pertama menempatkan nilai tinggi terhadap paradigma teori mereka sendiri, saling bekerjasama antar perspektif yang ada diluar mainstream atau ortodoks dan berkomitmen untuk membangun suatu komunitas ekonomi di luar mainstream dengan integrasi teori dan profesionalisme (Garnet, Olson \& Starr, 2009: 4); Lee, (2010), maka gelombang pluralisme 
kedua ini merupakan aspirasi keanekaragaman pluralisme yang dilandasi oleh pemikiran Mill (1975): a "positive valuing of a diversity of views in the minimal sense that one who is so commited would not want to reduce the number of available narrative or views" (HargreavesHeap 2001: 356; Garnet, Olson \& Starr, 2010: 4), dan Lawson (2003: 99) menyederhanakan dengan penegasan, penerimaan, dan dorongan untuk keberagaman. Pluralisme gelombang kedua ini mencoba mengemukakan kembali konsep "thingking like an economist" tetapi bukan "thingking like tradisional microeconomist", melainkan seni berfikir secara lebih luas untuk memperoleh kesimpulan ekonomi dalam mengahadapi ketidakpastian analisis, empiris dan normatif (Colander \& McGoldrick 2008; Knoedler \& Underwood 2003). Pluralisme yang diperkenalkan oleh Mills ini lebih bersifat humanistik, lebih memberikan ruang untuk kebebasan berekspresi yang bermakna keberagaman perilaku, saling bekerjasama antar perspektif, mengedepankan dialog, toleransi, dan usaha bersama kearah penyatuan perspektif yang berbeda.

\section{Pluralisme Ekonomi}

Pluralisme ekonomi dimaknai sebagai komunikasi terbuka, sikap kritis, dan keinginan bekerjasama antar teori, metodologi, pendekatan empiris dalam pengumpulan dan analisis data, serta membuat rekomendasi kebijakan (Staveren, 2011: 4). Keberadaan pluralisme ekonomi ini berdasarkan pada anggapan bahwa tidak ada satu teoripun yang dapat menjelaskan keadaan dunia yang begitu kompleks (ontologi) (Dow, 1996, 1997, 2008; Mäki 1997; Helcombe, 2008), dan (epitemologikal) menyatakan bahwa tidak ada satu standarpun yang bisa menyatakan bahwa satu teori itu adalah yang terbaik, sementara yang lainnya merupakan kekeliruan (Budzinski, 2008; Mearman, 2007). Pluralisme ekonomi ini bekerja berdasarkan postpositivisme ontologi dan epistemologi ekonomi yang sudah berkembang sekitar tahun 1980-an, beberapa diantaranya adalah pragmatis, post modernis, Marxis, Post Marxis, Keynesian, PostKeynesian, Feminist, institusionalis dan sebagainya (Tribe, 1978; Resnick \& Wolff , 1982; McClosky, 1983; Klamer, 1983; Lavoie, 1990; Lawson, 1994). Penerapan pluralism ekonomi ini mendapatkan dukungan yang semakin luas dari para dosen dan mahasiswa di Perancis, Inggris, Amerika Serikat, dan Italia
NIAGAWAN Vol 8 No 3 November 2019 pada tahun 2000 dan 2001, hingga terbentuklah gerakan the Post-Autistic Economics (PAE) yaitu gerakan yang menyerukan perubahan dan perbaikan total terhadap ekonomi dan pembelajaran ekonomi dengan prinsip pluralisme (Fullbrook, 2003; 8-9):

(a pluralism) that regards the various "school" of economics, including neoclassicalism, as offering different windows on economic reality, each bringin into view different subsets of economic phenomena...(and) reject the idea that any school could possess final or total solutions, but accepts all as possible means for understanding real-life economic problems.

Pluralisme ekonomi inilah yang dianggap sebagai cita-cita dan harapan yang diinginkan oleh mahasiswa dan perguruan tinggi (Garnett, 2006: 523): an epistemologically consistent pluralism that seeks to enhance the substantive intellectual freedoms of economists and their stakeholders, including our graduate and undergraduate students (Fullbrook, 2003; McIntyre, 2003). Dalam pluralime ekonomi, perspektif heterodoks dan persspektif ortodoks saling bekerjasama dalam menyelesesaikan persoalan-persoalan ekonomi yang dihadapi dunia.

Disamping itu, pluralisme ekonomi dianggap penting untuk meningkatkan kemampuan berfikir kritis dan reflektif mahasiswa. Pluralisme ekonomi juga melatih dan mengajak mahasiswa untuk lebih aktif dalam konten pembelajaran dalam konteks teori, metode, metodologi, model dan lainnya yang berbeda.

Pluralisme dianggap penting untuk meningkatkan kemampuan berfikir kritis dan refleksif mahasiswa. Pluralism mengajak mahasiswa untuk aktif terlibat dalam konten pembelajaran. Bahkan Mclennan (1995: 25) mengemukakan bahwa pluralisme menggemakan preferensi untuk keberagaman daripada keseragaman yang bermanfaat secara social. Dengan memperkenalkan pluralisme ekonomi yang menghasilkan pendidikan yang beragam, mahasiswa akan lebih banyak memiliki pengetahuan berbagai perspektif dan metodologi dalam ekonomi dan dampaknya adalah mahasiswa akan lebih bersikap kritis dan reflektif dalam membandingkan antar perspektif yang berbeda (O'Donnell, 2009).

\section{Berfikir Kritis}

Pertanyaan yang selalu muncul seperti yang dikemukakan oleh O'Donnell (2002: 1) 
NIAGAWAN Vol 8 No 3 November 2019

"apa sebenarnya yang kita harapkan siswa kuasai diakhir studi mereka" masih terus berlanjut. Salah satu tujuan dalam proses pembelajaran di perguruan tinggi adalah supaya mahasiswa dapat berfikir kritis. Tuntutan ini muncul seiring dengan kebutuhan pasar tenaga kerja di era informatika saat ini. Para mahasiswa harus benar-benar dipersiapkan untuk memiliki berbagai kemampuan yang menjadikan mereka pemikir sistem, pemecah masalah dan mampu memutuskan secara mandiri. Oleh karena itu, setiap mahasiswa harus memiliki kemampuan berfikir kritis. Kita mulai dengan pemikiran kritis yang berasal dari Konsensus disiplin ilmu, dan digunakan secara luas dalam pengajaran dan penilaian pemikiran kritis yaitu:" Critical thinking is the prosess of the purposepu, self regulatory judgment. This process gives reasoned consideration $\mathrm{t}$ evidnce, contexts, consepualizations, methods, and criteria." (American Philosophical Association Delphi Report, 1990). Lebih lanjut, Schafersman (1991; 3) juga mengatakan bahwa berfikir kritis merupakan kegiatan berfikir dengan benar untuk memperoleh pengetahuan yang relevan dan reliable. Hampir sama dengan pendapat tersebut, Ennis (1993: 180) juga berpendapat bahwa berfikir kritis adalah pemikiran yang masuk akal dan reflektif dan berfokus pada apa yang seharusnya dipercaya atau dilakukan. Jadi, berfikir kritis itu bisa dimaknai sebagai sesuatu yang dilakukan dengan penuh kesadaran mengarah kepada suatu tujuan yang memungkinkan untuk membuat keputusan. Gülşah Külekçi dan Esin Kumlu (2015: 77) lebih jauh mengungkapkan bahwa "Critical thinking can be defined as the ability of thinkers to take charge of their own thinking and develop sound criteria and standards for analyzing and assassing their own thinking. Begitu pula Feldman (2010: 4) berpendapat bahwa berfikir kritis meliputi tindakan untuk mengevaluasi situasi, masalah atau argument, dan memilih pola investasi untuk mendapatkan jawaban yang terbaik. Dapat disimpulkan bahwa berfikir kritis dalam hal ini dapat dimaknai sebagai kemampuan mahasiswa dalam hal menyelesaikan masalah dengan cara menganalisis asumsi, memberi rasional, mengevaluasi, melakukan penyelidikan serta keberanian mengambil keputusan. Pemikiran kritis itu melibatkan "mengidenifikasi dan menantang asusmi dan mengeksplorasi cara-cara alternative berfikir dan bertindak (Brookfield.
1987: 71). Siswa yang berfikir kritis harus dapat memisahkan fakta dari pendapat, terutama dalam menganalisis perspektif teori yang berbeda, memahami premis yang mendasarinya, dan mengevaluasi masing-masing dengan informasi dan alasan pembenaran. Berfikir kritis bisa dirangsang lewat pemberian masalah atau pertanyaan, dimana pertanyaan tersebut tidak memiliki jawaban yang tunggal. Dalam penelitian ini, indikator berfikir kritis yang digunakan dalam penelitian ini adalah keterampilan menganalisis, mengevaluasi informasi, mensintesis bukti, dan menarik kesimpulan menggunakan penalaran deduktif dan induktif. Dalam membangun kebiasaan berfikir kritis, dosen harus menggunakan tugas yang bersifat open ended, permasalahan autentik, menggunakan konteks dunia nyata, dan masalah yang tidak terstruktur sehingga mengharuskan mahasiswa untuk mengingat dan mengatakan kembali informasi yang dipelajari sebelumnya (Lai; 2011). Tugas yang diberikan juga memberikan solusi lebih dari satu, dan dapat dipertahankan dengan materi yang memadai untuk mendukung berbagai perspektif. Oleh sebba itu, tugas yang semacam ini bias memperlihatkan penalaran mahasiswa yang diperlihatkan dengan bukti atau argument logis yang dapat mendukung penilaian, pilihan ataupun pernyataan.

\section{METODE PENELITIAN}

Penelitian ini merupakan penelitian deskriptif kuantitatif yang dilakukan di Fakultas Ekonomi Universitas Negeri Medan. Subjek penelitian adalah mahasiswa $\mathrm{S} 1$ pendidikan ekonomi yang berjumlah 40 orang. Data kemampuan berfikir kritis mahasiswa diperoleh melalui instrument penelitian berupa soal tes, rubrik indikator kemampuan berfikir kritis, serta pedoman wawancara. Soal tes terdiri dari tiga soal. Soal pertama berupa openended test, soal kedua mempunyai struktur yang tidak lengkap dan soal ketiga memuat informasi yang tidak konsisten. Selanjutnya dilakukan penyusunan indikator berfikir kritis yang terdiri dari keterampilan menganalisis argument, mengevaluasi informasi, mensintesis bukti dan penarikan kesimpulan dengan menggunakan penalaran deduktif dan induktif. Pedoman wawancara digunakan untuk memeproleh informasi yang tidak lengkap dari jawaban mahasiswa. Kemudain hasil tes mahasiswa dianalisis menggunakan indikator berfikir kritis 
dengan menggunakan persentase. Hasil tes juga didukung hasil wawancara subjek penelitian.

\section{HASIL DAN PEMBAHASAN}

Tes kemampuan berfikir kritis mahasiswa diberikan pada mahasiswa Pendidikan Ekonomi semester 2 yang diperkenalkan pertama sekali dengan pluralisme dalam makroekonomi. Setelah mahasiswa diberikan tes, kemudian hasilnya dianalisis dengan menggunakan rubrik ketercapaian indikator kemampuan berfikir kritis. Hasil analisis memperlihatkan bahwa pada soal no. 1, terdapat 37 mahasiswa atau $92,5 \%$ mahasiswa sudah mencapai indikator menganalisis argumentasi, 35 mahasiswa atau 87,5\% mahasiswa sudah mencapai indikator mengevaluasi informasi dan mensintesis bukti, dan 34 mahasiswa atau 85\% mencapai indikator menarik kesimpulan dan menyelesaikan masalah sesuai dengan bukti yang ada. Setelah dilakukan wawancara, diperoleh inoformasi bahwa mahasiswa dapat menyelesaikan permasalahan karena terbiasa untuk menyelesaikannya.

Pada soal no 2, terdapat 36 mahasiswa atau $90 \%$ yang telah mencapai indikator menganalisis argument dan mengevaluasi informasi, 34 mahasiswa atau $85 \%$ yang telah mencapai indikator mensintesis bukti dan 33 mahasiswa atau $82,5 \%$ yang telah mencapai indikator menarik kesimpulan. Setelah dilakukan wawancara terhadap mahasiswa yang tidak dapat menarik kesimpulan diperoleh informasi bahwa mereka mengalami kebingungan terhadap beberapa perspektif yang berbeda.

Berdasarkan pada soal no 3, diperoleh hasil bahwa 36 mahasiswa atau 90\% udah mencapai indikator menganalisis argument, 35 mahasiswa atau $87,5 \%$ telah mencapai indikator mengevaluasi informasi dan mensintesis bukti sedangkan 3 mahasiswa atau 7,5\% tidak mencapai indikator menarik kesimpulan. Setelah dilakukan wawancara, ternyata mereka menagtakn ada ketidaksesuaian antara informasi dan gambar yang diberikan, sehingga soal tidak dapat dikerajakan.

Dengan data yang telah dipaparkan, maka dapat ditarik kesimpulan bahwa rata-rata mahasiswa atau 90,8\% mencapai indikator menganalisis argument, 88,3\% mahasiswa telah mencapai indikator mengevaluasi informasi, 86,7\% mahasiswa telah mencapai indikator mensintesis bukti dan $86,7 \%$ telah mencapai indikator menarik kesimpulan. Kendala yang
NIAGAWAN Vol 8 No 3 November 2019

dihadapi mahasiswa ketika dilakukan wawancara adalah beberapa mahasiswa bingung dengan beberapa perspektif yang berbeda serta kesalahan indormasi dan gambar yang tidak sesuai dengan soal. Kepercayaan informasi yang diberikan sangat penting dalam pengambilan keptusan. Pada saat informasi yang diberikan tidak lengkap, maka akan menimbulkan persepsi yang berbeda sehinggi mempengaruhi kesimpulan mahasiswa menjadi kurang tepat.

\section{KESIMPULAN DAN SARAN}

Pluralism ekonomi mampu meningkatkan kemampuan berfikir kritis mahasiswa. Pluralism ekonomi menyiratkan toleransi terhadap keragaman sudut pandang dan keterlibatan kritis mahasiswa dengan ide-ide yang beraneka ragam. Mahasiswa juga lebih memahami bahwa ada jawaban untuk berbagai fenomena ekonomi. Selain itu, Kemampuan menganalisis, mengevaluasi informasi, mensintesis bukti serta kemampuan menarik kesimpulan dari berbagai perspektif teori yang berbeda juga semakin meningkat. Dari hasil penelitian yang telah dilakukan dan berdampak sangat positif terhadap kemampuan berfikir kritis mahasiswa, maka sudah selayaknya pluralime ekonomi semakin dikembangkan dan diterapkan dalam mengajarkan ekonomi kepada mahasiswa.

\section{REFERENSI}

American Philosophical Association (APA). 1990. Critical Thinking: A Statement of Expert Consensus for Purposes of Educational Assessement and Introduction, Recommendations Prepared for the Committee on PreCollege Philosophy. Eric Doc, No. ED $315-423$

Arnsperger, C., and Y. Varoufakis. 2006. What is neoclassical economics? Post-Autistic Economics Review 38: article 1

Backhouse, R. E. 2001. On the credentials of methodological pluralism, in: J. E. Biddle, J. B. Davis \&S. G. Medema (Eds) Economics Broadly Considered: Essays in Honor of Warren J. Samuels, hlm 161-181(London: Routledge).

Brookfield, S.D. 1987. Developing Critical Thinkers: Challenging Adults to Explore Alternative Ways of Thingking and Acting. San Fransisco: Jossey-Bass 
Budzinzki, O. 2008. Monoculture versus Diversity in Competition Economics. Cambridge Journal of Economics, 32 (2): $295-324$

Denis, A. 2009. Editorial: Pluralism in Economics Education. International Review of Economics Education, 8 (2), 6-21

Desai, M. 1979. Marxian Economics. Oxford: Basil Blackwell

Dolan, E. G. 1976. Austrian Economics as Extraordinary Science, in: E. G. Dolan (Ed). The Foundation of Modern Austrian Economics, pp. 3-18. Kansas City: Sheed \& Ward

Dow, S. 1996. The Methodological Pluralism and Pluralism of Method, in: A. Salanti \& E. Screpanti (Eds) Pluralism in economics, hlm. 89-104. Cheltenham: Edward Elgar.

Dow, S. 2008. Plurality in Orthodox and Heterodox Economics. Journal of Philosophical Economic, 1 (2); 73-96.

Ennis, R.H. 1993. Critical Thinking Assessment. Theory Into Practice, 32 (3): 179-189

Feldman, A. D. 2010. Berfikir Kritis: Strategi untuk Pengambilan Keputusan. Jakarta Barat: Pt. Indeks

Fullbrook, E. (ed). 2003. The Crisis in Economics. The Post-Autistic Economics Movement: The First 600 Days, London: Routledge.

Fullbrook, Edward. 2009. The Meltdown and Economics Textbooks. Dalam Jack Reardon, ed. The Handbook of Pluralist Economics Education, London, Routledge: 17-23.

Garnett, R. 2006. Pluralism, Academic Freedem, and Heterodox. Review of Political Economic, 18 (4): 521-546.

Garnett, Robert, Erik Olsen and Martha Starr. 2010b. Economic Pluralism for the Twenty-first Century. in Robert Garnett, Erik Olsen and Martha Starr (eds.) Economic Pluralism. Abingdon: Routledge: 1-15.

Gülşah Külekçi \& Esin Kumlu. 2015. International Journal Of Language Academy Developing Critical Thinking Skills In English Language Teaching Classes. International Journal of Language Academy, 3, 76-90
Hargreaves-Heap, S. 2001. Postmodernism, Rasionality, in: S. Cullenberg, J. Amariglio \& D.

Colander, D. dan K. McGoldrick. 2010. The Teagle Foundation Report: The Economics Major as Part of a Liberal Education', in Colander, D. dan McGoldrick, K. (eds) Educating Economists: The Teagle Discussion, Northampton, MA: Edward Elgar: 3-39

Holcombe, R.G. 2008. Pluralism versus Heterodoxy in Economics and The Social Science. The Journal of Philosophical Economics, 1 (2): 51-72.

Jacson, Willian Anthony. 2017. Strategic Pluralism and Monism in Heterodox Economics. Review of Radical Political Economics. hlm.1-15.ISSN 0486-6134 https://doi.org/10.1177/0486613416670 $\underline{971}$

Juniper, James, Bill Mitchell, Andrew Nadolny dan Martin Watts. 2015. Designing a Heterodox Program of Macroeconomics. Centre of Full Employment and Equity. The University of New Castle: NSW, Australia

Klamer, A. 1984. Conversation with Economists: New Clasical Economics and Their Opponents Speak Out on the Current in Macroeconomics. Totowa, NJ: Rowman and Littlefield

Knoedler, J. and D. Underwood. 2003. Teaching the principles of economics: a proposal for a multi-paradigmatic approach. Journal of Economic Issues, 37 (3): 697725.

Kregel, J. 1975. The Reconstruction of Political Economy: An Intriduction to PostKeynesian Economics. London: Macmillan

Lai, Emily. R. 2911. Critical Thinking: A Literature Review. Pearson's Research Reports

Lawson, T. 1994. The Nature of Post Keynesianism and its Links to other Traditions: A Realist Perspective. Journal of Post Keynesian Economics. 16: 503-37.

Lawson, T. 2003. Reorienting Economics. London: Routledge

Lavoie, D. (ed). 1990. Hermeneutics and Economics. London: Routledge 
Lee, Frederic. 2009. A History of Heterodox Economics- Challenging the Mainstream in the Twentieth Century, London, Routledge.

Lee, F.S. 2010. A Case for Ranking Heterodox Journals and Departments. On the Horizon 16, 4: 241-251

Lee, F.S. 2011. The Pluralism Debate in Heterodox Economics. Review of Radical Political Economics 43(4): 540551.

Mäki, Uskali. 1997. The One World and the Many Theories. Pluralism in Economics Ed. Andrea Salanti and Ernesto Screpanti. Cheltenham: Elgar.

Mankiw, N. Gregory. 2008. Principles of Economics. $5^{\text {th }}$ edition. South -Western College.

Marqués, Gustavo dan Diego Weisman. 2010. Is Kuhnean Incommensurability a Good Basis for Pluralism in Economics? In Economic Pluralism, edited by Robert Garnett, Erik K. Olsen and Martha Starr, pp. 74-86. London: Routledge.

McCloskey, D.N. 1983. The Rhetoric of Economics, Journal of Economic Literature, 21: 481- 517

Mearman, A. 2007. Teaching Heterodox Economic Concepts. in P. Davies (Ed.) Handbook for Economics Lecturers, Bristol: Economics Network of the Higher Education Academy. (Online) (http://www.economicsnetwork.ac.uk/ha ndbook/heterodox/), diakses 10 Mei 2015.

Mill, John Stuart.1975. On Liberty. Middlesex: Penguin.

Mubyarto. 1987. Ekonomi Pancasila, Gagasan dan Kemungkinan. Jakarta: LP3ES

Negru, I. 2010. Plurality to Pluralism in Economics Pedagogy: The Role of Critical thinking. Internasional Journal of Pluralism and Economics Education, 1 (3).

O’Donnell, R. 2009. Economic Pluralism and Skill Formation: Adding Value to Students, Economies, and Societies. in R. Garnett, E. Olsen, and M. Starr (eds), Economic Pluralism, London: Routledge: 262-77.

O'Donnell, R. 2002. What Kind of Economics Graduates Do We Want? A Constructive Critique of Hansen's Proficiencies Approach. WorKIng Paper No 203,
NIAGAWAN Vol 8 No 3 November 2019 Macquarie University, Department of Economics. (Online), http://www.econ.mq.edu.au/research/20 02/3-2002_ODonnell.pdf, diakses 4 April 2015

Patunru, Arianto.A. 2013. Pengajaran Mikroekonomi di FE UI: Sebuah Pengalaman. Jakarta. 60 Tahun FE UI.

Raveaud, G. 2009. A Pluralist Teaching of Economics: Why and How. in R. Garnett, E. Olsen, and M. Starr (eds), Economic Pluralism, London: Routledge: 250-61.

Resnick, S. \& Wolff, R. 1988. Marxian Theory and the Rhetorics of Economics, in: A. Klamer, D. N. Mc. Closkey \& R. M. Solow (eds) The Consequences of Economic Rhetoric. Cambridge: Cambridge UniversityPress, pp. 47-63

Shadmehri. M. Taher Ahmadi, Fazeleh Khadem \& Alireza Ghadimi. 2014. Economic Schools Thought: Mainstream, Ortodox and Heterodox Economics. Kuwait Chapter of Arabian Journal of Business and Management, 3 (12a) August.

Samuelson, Paul and William Nordhaus. 2009. Economics. $19^{\text {th }}$ edition. McGraw Hill/Irwin.

Santosa, Purbayu Budi. 2010. Kegagalan Aliran Ekonomi Neoklasik dan Relevansi Aliran Ekonomi Kelembagaan dalam Ranah Kajian Ilmu Ekonomi. Pidato Pengukuhan. Badan Penerbit Universitas Diponegoro. Semarang. ISBN: 978-979704-891-4

Schafersman, S.D. 1991. An Introduction to Critical Thinking. (Online), http://facultycenter.ischool.syr.edu/wpcontent/uploads/2012/02/CriticalThinkin g.pdf , diakses 4 September 2016

Tool, M.R. 1979. The Discretionary Economy: A Normative Theory of Political Economy. Santa Monica, CA: Goodyear Publising Co.

Tribe, K. 1978. Land, Labour, and Economic Discourse. London. Routledge and Kegan Paul 